\title{
Structure and Inheritance Of The Carita Pantun Oral Tradition
}

\author{
Arif Firmansyah $^{1 *}$, Aceng Rahmat ${ }^{2}$, Siti Gomo Attas ${ }^{3}$ \\ Jakarta State University ${ }^{1,2,3}$ \\ \{ariffirmansyah@gmail.com ${ }^{1}$ \}
}

\begin{abstract}
This research examines of the Carita Pantun oral tradition in Sadawarna village, Cibogo district, Subang district, with the main focus on analyzing the performance structure and its inheritance. This type of research is descriptive qualitative by making observations and direct interviews with sources, namely the Juru Pantun. In this study, it was found that pre-performance activities included preparing offerings, praying and reciting mantras before leaving for the chant, praying and reciting mantras when climbing on the stage, praying when picking kacapi, and completing prayer. The stages of the show include opening, patwa, and lalakon. The event closed with a prayer and apology. Then Juru Pantun invited the audience to eat the offerings together. The inheritance of Carita Pantun in Subang is carried out by the Juru Pantun by training some of its students, making stories that are sung in a language that is easily understood by the community, and creating new stories. The stories that are usually sung are titled Batu Ali-Ali Ampal and Nyi Subang Larang. The show was held at a thanksgiving ceremony for 40 days for babies, and was held at home by the Juru Pantun with the accompaniment of kacapi. The implication of this research is expected to provide benefits for the continuity of the oral tradition of Carita Pantun so that this tradition can survive and be recognized by the public again.
\end{abstract}

Keywords: Structure; Inheritance; Carita Pantun.

\section{Introduction}

Oral literature reflects the symbols of the cosmos which are deliberately made to be reinterpreted into the values of life, these symbols become historical records and can be reflected in this era of globalization. The variety is very large and has very many variations as well. The content may be about various events that have occurred or the culture of the people who own the literature (Finnegan, 2018). However, its development as a result of past culture that helped shape the civilization of the archipelago, oral literature has begun to recede with people's unconsciousness about the importance of noble values. The decline in the love of future generations for oral literature is because this tradition is considered unsuitable for practice in the modern world (Badrih, 2018). 
The main factor that causes this cultural shift is the lack of appreciation of society for their own culture (Teeuw, 1994) The extinction of oral literature is largely due to the breakdown of inheritance from one generation to the next (Nurtikawati;Salniwati, 2016). As happened in the Carita Pantun show which is increasingly being abandoned. Carita Pantun is the oldest traditional art in West Java. In 1518 AD, the existence of the Carita Pantun in West Java was recorded by the manuscript Siksa Kandang Karesian, at that time the title of the poem called Langgalarang, Banyakcitra, Siliwangi, and Haturwangi (Ruhaliah, 2017). Carita Pantun are different from pantun in Malay literature. Carita Pantun are the art of telling stories and singing with a lute accompaniment (Sumardjo, 2003) " the play Carita Pantun tells a story from the past (baheula) about kings or sons and daughters of kings from Pajajaran descent.

Given the importance of cultural inheritance in society, the inheritance pattern must be examined. Ajip Rosidi made efforts to inherit the oral tradition of the Carita Pantun in the 1970s by recording 30 poetry titles, inventoriing the types of stories displayed, transcribing and publishing 16 titles of pantun stories. however, the revitalization effort ended in 1973. The results of the recording were contained in an article entitled My Experiences in Recording "Pantun Sunda" (Rosidi, 1973).

Next comes a few researchers who examine Carita Pantun, among others: Some notes on the poetry storytelling of the Bedouin minority group: Its written and audiovisual documentation (Van Zanten, 2016) this research document Carita Pantun in Baduy and compare some text Carita Pantun exist in several regions. The research entitled Paradoxical Figure and Application in Carita Pantun Sunda by (Darisman, 2019), this study interprets the characters in the Carita Pantun with the people's beliefs. In line with several studies that have been conducted, this study aims to examine the structure and inheritance of the carita pantun, as an effort to revitalize the oral tradition of the Carita Pantun.

\section{Method}

This research uses qualitative research. The research was built on the basis of data in the field which was developed based on research objectives. The data source was a Juru Pantun, namely Mang Ayi Basajan, whose address is in Sadawarna village districts Cibogo, district Subang, West Java. The data collection techniques used in this study were interview techniques and recording techniques. The interview technique that researchers will use in data collection is the undirected technique (Danandjaja, 2007). Interviews conducted with sources as a source of information. will be recorded using a recording device. Information obtained from the source is in oral form which is then transcribed into written or text form. Then the information was edited and translated from Sundanese into Indonesian. The results of this recording technique will be used as research data.

\section{Results and Discussion}

Carita Pantun is a sacred art and has something to do with the mystical because there are hidden mantras. The word pantun means papatah bari nuntun. The person who speaks the Carita Pantun is called the interpreter. The delivery is in Sundanese language and the accompaniment of the lute musical instrument. In the Subang area, the Carita Pantun is often used to treat first children, only children, and ruwatan a house or land. Stories that are often 
performed in performances entitled Ciung Wanara, Mundinglaya Dikusuma, Lutung Kasarung, Nyi Subanglarang's Marriage, Eyang Sri Wangi, Batu Ali Ali Ampal and Ieuweung Larangan. There are stories related to the mystical and only used when ruwatan a village called Carita Pantun Eyang Mangkubumi. The aspects contained in the art of carita pantun, including:

\subsection{Player / speaker}

Players / speakers of Carita Pantun are male, usually in a show there is only one pantun interpreter. but in Subang, namely in the Mang Ayi Basajan studio, a performance can be led by one or two composers depending on the readiness of the Juru Pantun. For example, when the performance was held at his house, and at the 40 day baby event in the Tanjung Ari Subang area, the Juru Pantun was accompanied by Wa Didi who gave an alokan or response to the story of the Juru Pantun.

Ka Dulur kaula nu opata kalima pancer (sumuhun)

Ka Dulur kaula nu genep ka seven pancer (sumuhun)

For example, the sentences Ka Dulur kaula nu opata kalima pancer and Ka Dulur kaula nu genep ka tujuh pancer were pronounced by Mang Ayi. While the word sumuhun was uttered by Wa Didi in response to Mang Ayi's story. It is different when the show is held outside the Subang area, namely in Bandung in a ritual ceremony for the bride and groom, the singer of the carita pantun is only Mang Ayi Basajan.

\subsection{Clothing (Costumes)}

The costumes worn by the Juru Pantun during the performance are Pangsi clothes in black or white, the color has its own meaning, black means being steadfast in one's stance and white means purity of heart. In addition to the pangsi, the juru pantun also uses iket (a headband made of batik cloth).

\subsection{Time}

This Carita Pantun performance usually lasts all night starting after Isya until just before fajr. The narrative is done by memorizing it orally (Rosidi, 2000). But now the carita pantun performed by Mang Ayi is adjusted to the request of those who have a desire. Can be done day or night. This indicates a change in this performance carita pantun which usually lasts all night starting after Isya until before Fajr. The narrative is done by memorizing it orally (Rosidi, 2000).

\subsection{Equipment}

The only equipment used in the art of Carita Pantun is a lute, which functions to accompany the passage of a carita pantun.

\subsection{Offerings}

In the performance carita pantun cannot be separated from the ceremonial instruments as a condition that must be presented before the Juru Pantun performance begins, such as incense. Through the burning of the incense, it is hoped that the inhabitants of the Upper World can attend the performance which will be told by Juru pantun (Sumardjo, 2003). In addition, there is also an offering which means the syarat sangka jentre sarasa jeung saajen. The purpose of using offerings is to appreciate the work of ancestors, and to express gratitude. Offerings are prepared by those who have a desire, including: a. Puncak Manik signifies the ideals of officials to their people who must have a caring soul, b. duwegan, in the past, 
ancestors often drank deuwegan water, therefore it was used as one of the offerings to remind each other of the ancestors, c. Hanjuang has a symbol of the journey of Grandparent King Sumedang, d. seven kinds of fruits symbolize the day or time, e) Hahampangan contains cakes, and dodol means to lighten the burden, f) Rujak Pisang, Rujak Kelapa, Rujak Asem, Rujak Kopi, which means that the unity that exists in humans has a sour taste, a sweet taste. Flowers symbolize mutual liking, h) Sweet coffee water, bitter coffee water, sweet tea, and bitter tea are symbols of balanced human life, i) rice, roasted bananas, salted fish, shrimp paste, red chilies are symbols of food that our ancestors liked, Bako Tampang, kawung leaves are also favorites of the ancestors, $\mathrm{k}$. powder, glass, comb, and mermaid parfume symbols to beautify oneself. The composition of the show consists of opening or Rajah, namely begging and surrendering to the god the creator, in order to be safe and away from all kinds of dangers. Furthermore, patwa, contains an introduction before the show begins, and lalakon / story.

\section{Conclusion}

Carita pantun show has undergone several changes, it is adjusted to the times, such as the performance time which changes from all night to 24.00 and the performance can be day or night. The language used is made simpler in order to attract the younger generation to be more interested. Various efforts have been made in order to inherit the Carita Pantun, such as establishing a Dangiang linggar manik, training its students, performing performances, and making Mang Ayi's version of the story.

\section{References}

[1] Attas, S. G. (2019). Structure, Function, And Inheritance System Of The Gambang Rancag Oral Tradition In The Betawi Community. Litera, 18(1), 118-135.

[2] Badrih, M. (2018). Sastra lisan (kèjhung) sebagai tfransformasi simbol pendidikan berkarakter budaya daerah. International Good Practices in Education Diciplines and Grade Leve, (November), 289-303. Retrieved from https://www.researchgate.net/publication/329177472

[3] Danandjaja, J. (2007). Folkor Indonesia. Jakarta: Grafiti.

[4] Darisman, A. (2019). Paradoxical Figure And Application In Carita Pantun Sunda. Balong International Journal of Design. https://doi.org/10.25134/balong.v2i2.2424

[5] Finnegan, R. (2018). Oral Poetry: Its Nature, Significance and Social Context. London: Cambridge University Press.

[6] Lord, A. B. (2000). The Singer of Tales Second Edition. London: Harvard Harvard University Press.

[7] Nurtikawati;Salniwati. (2016). Nilai Budaya dan Pola Pewarisan Sastra Lisan di Sulawesi Tenggara: Pendekatan Tradisi Lisan Sulawesi Tenggara merupakan daerah yang sangat banyak dijumpai kha-. Etnoreflika, 5, 238-245.

[8] Rosidi, A. (1973). My Experiences in Recording " Pantun Sunda ". JSTOR, 16(16), 105-111. Retrieved from http://www.jstor.org/stable/3350648

[9] Rosidi, A. (2000). Ensiklopedi Sunda., Alam, Manusia dan Budaya. Jakarta: Pustaka Jaya.

[10] Sumardjo, J. (2003). Arkeologi budaya Indonesia : pelacakan hermeneutis-historis 
terhadap artefak-artefak kebudayaan. Yogyakarta: Qalam.

[11] Teeuw, A. (1994). Indonesia Antara kelisanan dan Keberaksaran. Jakarta: Pustaka Jaya.

[12] Van Zanten, W. (2016). Some notes on the pantun storytelling of the Baduy minority group: Its written and audiovisual documentation. Wacana, 17(3), 404-437. https://doi.org/10.17510/wacana.v17i3.454 